
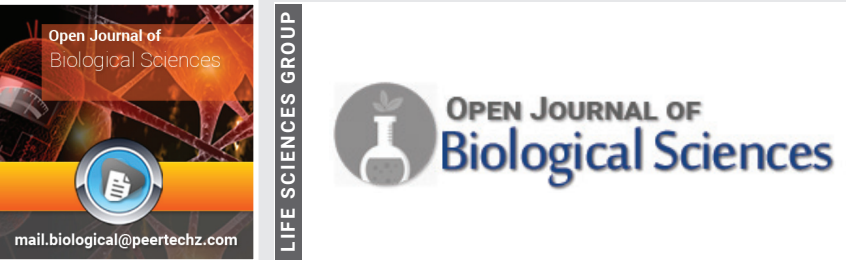

\section{Phytochemical screening and antimicrobial activity of crude extract of Tithonia diversifolia}

\section{Oloo Merciline and Menge Dominic*}

Department of Biological Science, Maasai mara University, P.O Box 861-20500, Narok, Kenya
Received: 18 May, 2020

Accepted: 13 June, 2020

Published: 15 June, 2020

*Corresponding author: Dr. Menge Dominic, Ph.D, Lecturer, Physiological plant pathologist, Department of Biological Sciences, Maasai Mara University, P.O Box 861-20500, Narok, Kenya,

E-mail: dominicmenge@yahoo.co.uk; menges@mmarau.ac.ke

Keywords: Antimicrobial activity; Antifungal activity; Crude extracts; Phytochemical; T. diversifolia

https://www.peertechz.com

\begin{abstract}
Tithonia diversifolia is a tropical woody herb or succulent shrub cultivated in many countries; it's an annual or perennial medicinal plant that has been a subject of research due to its various benefits in the treatment of different kinds of ailments. The aim of this study was to extract secondary metabolites from leaves, stems and roots of Tithonia diversifolia to evaluate their efficacy. Leaves, stems and roots of $T$. diversfolia were collected around Maasai Mara University and taken to laboratory for identification. The plant parts of interest were then washed dried for twenty-one days then were grounded into powder. The grounded powders were used to make concentrations by the use of distilled water, acetone and methanol as the solvents. Phytochemical screening was carried out to evaluate the presence of secondary metabolites which included test for tannins, saponins, terpenoids, alkaloids, glycocides, steroids and flavonoids. The extracts from leaves, stems and roots of $T$. diversofolia were investigated for antibacterial and anti-fungal activity on standard test organisms using agar disk-diffusion method. The use of punched filter papers dipped in the various concentrations were subjected into plates with nutrient agar containing standard test organisms e.g. Pseudomonas aeruginosa, Escherichia coli, Candida albicans and Staphylococcus aureus. The results for the phytochemical analysis of the extracts indicated the presence tannin flavonoids and alkaloids in all the plant parts and in all the solvents used. Results obtained from antimicrobial activity testing of crude extracts of $T$. diversifolia, showed variability in the inhibitory activity of $T$. diversifolia crude extracts against the test organisms. Among all the microorganisms used $S$. aureus is much more susceptible to the crude leaves extracts showing the highest inhibitory zone followed by methanolic extracts. The presence of these phytochemical and their ability to react against tests organisms indicates that the leaves, roots and stems of $T$. diversifolia could serve as basic ingredients in drug making for use in treatment of various ailments.
\end{abstract}

\section{Introduction}

The spread of emergence of multiple drugs derived from medicinal plants have been an encouragement to the scientist to constantly search for natural products as a source of new drugs that can act as an alternative to the already existing drugs. Research has been done on the determination of antimicrobial efficacy and properties of various plant extract, however continued research in this area is still promising, this is because of the emergence of new diseases that could either be treated by the use of natural products. Therefore scientists have been subjected to a constant search for medicinal plants with therapeutic potential.

T. diversifolia plant species are perennial herbs, typical woody herb or succulent shrub-like, cultivated in many areas of the world. This invasive plant species grows up to the height of three meters and ten centimeters wide in disturbed areas and can withstand heat and drought. It is studied because of its multipurpose benefits; the leaves have been used for treatment of various ailments them being stomach aches, sore throats, indigestion etc. [1]. Numerous literatures indicate that most of researchers have dealt with the screening of phytochemicals from the leaves of T. diversifolia ignoring its stems and roots. Aside from this, information on the secondary metabolites and proximate composition of the plant is very scanty Figure 1.

T. diversifolia is an important medicinal plant with its leaf considered as the major organs used solely or in combination with other plants for treatment of different ailments. Various researches have been done using leaves ignoring the roots and stems.

T.diversifolia has been used as a subject of research interest because of its various indigenous medicinal uses in Kenya. Pharmacological research of T. diversifolia indicates its possession of many active constituents including antimicrobial, ant-fungal, ant- malarial (Madureira, 2002) and cancer chemo preventive activities [2]. T. diversifolia are traditionally used for skin diseases, menstrual pain, hepatitis, treatment of diabetes, 


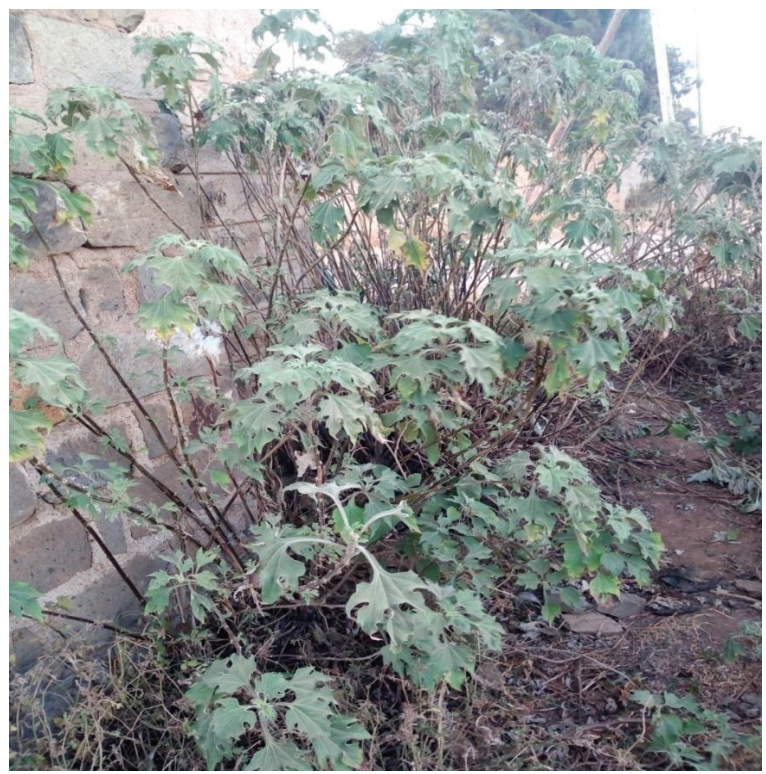

Figure 1: Tithonia diversifolia aerial parts.

diarrhea, wound healing among others, the effects of this drug are said to be attributed to the presence of terpenoids and flavonoids in its aerial parts. With the exploration and incorporation on the scientific understanding of plants, there has been the need to collect information on various kinds of plants that can be used in treatment of various specific ailments [3].

Secondary biologically active molecules contained within the leaves, roots and stems of T. diversifolia are described to be of importance, these secondary metabolites to be determined are the tannins, alkaloids, flavonoids, saponins steroids, terpenoids and glycosides.

In this study, crude extracts from the leaves, roots and stem of $T$. diversifolia will be used to test for the antimicrobial efficacy against bacterial and fungal pathogens, where the aim of this study was to establish whether extracts from $T$. diversifolia have an antimicrobial tendency against the fungal and bacterial pathogen.

\section{Methodology}

\section{Study site}

Maasai Mara University is located $1 \mathrm{~km}$ off Narok-Bomet highway and 2 kilometers from Narok town in Kenya. It is nationally located 150 kilometers of Nairobi capital city of Kenya. It has latitude of $1.083^{\circ} \mathrm{S}$ and $35.867^{\circ} \mathrm{E}$.

\section{Plant collection and identification}

Tithonia diversifolia parts were collected around Maasai Mara University in Narok County, Kenya during the SeptemberDecember 2019 season. The Five year (5) old plants were identified by a taxonomist in the department of Biological Science within the university laboratory. Voucher specimens were deposited in Maasai Mara university herbarium Table 1.

\section{Test organisms}

Four species of microorganisms were selected for the study which included Staphylococcus aureus, Escherichia coli, Pseudomonas aeruginosa and Candida albicans.

Extraction Plant parts; leaves, stems and roots of T.diversifolia were collected around Maasai Mara University. They were washed with clean water and rinsed with distilled water to remove debris and dried under a shade in an open air for a period of twenty days. The plants were then grounded into powder and powder stored in the plastic bags using a laboratory mortar and pestle. Approximately five grams of each plant extract were soaked in a quarter liter of each solvent for 72 hours to allow extraction of crude active compounds.

\section{Phytochemical tests}

Phytochemical screening of the crude extract for saponins, tannins, terpenoids, alkaloids flavonoids and steroids were done by the use of methods described best by Sofowora Evans and Harbone [4-6].

\section{Antimicrobial assays}

Filter paper disc $6 \mathrm{~mm}$ in diameter containing crude extracts were placed on the surface of solidified nutrient medium and the petri dishes incubated under favorable conditions for two to three days depending on the type of microorganism. Plant extracts diffused into nutrient medium and formation of an inhibition zone on surface of medium indicated antibacterial activity. The diameters of zones of inhibition were measured with respect to the diameter of the filter paper disk.

\section{Data analysis}

Antimicrobial activity of different plant parts and solvents used were compared using ANOVA, and separation means, over test, percentage of mean standard error was carried out. Micrographs were taken.

\section{Results}

\section{Presence or absence of Phytochemicals}

Table 2 shows phytochemical compounds present in methanolic, acetone and aqueous crude extract of the leaves, stems and roots of T. diversifolia. Presence of saponins in leaves and absence in both stems and roots extracted using methanol. In acetone saponins were absent in all the three plant parts. Using distilled water, saponins were present in all the plant parts used Figure 2.

All plant parts, leaves, stems and roots indicated the existence of flavonoids in distilled water, acetone and methanol (Table 2). Alkaloids were present in all the plant material used extracted using all the three solvents except only in roots extracted using acetone (Table 2).

Steroids were present in both leaves and roots and absent in stems extracted using methanol. Using acetone, steroids were only present in leaves and missing in both stems and roots. Using distilled water, steroids were present in leaves and missing in the two parts; stems and roots. 
In methanolic extract, terpenoids were absent in all the plant materials used. Terpenoids were only present in stems and leaves using acetone and methanolic extract respectively (Table 2).

Tannins were present in all the plant materials used extracted using methanol, acetone and distilled water. Glycosides were present in leaves, stems and roots extracted using methanol, in acetone, glycosides were present in leaves and absent in both stems and roots. Using distilled water, glycosides were present in both stems and leaves and absent in roots (Table 2 ).

\section{Antimicrobial activity}

There were remarkable variations in diameters of zones of inhibition from crude extract, methanolic extract and acetone extracts from leaves $(\mathrm{P}=0.0016)$. The greatest zone of inhibition

Table 1a: Zone diameter $(\mathrm{mm})$ of growth inhibition of extract from three plant parts against s. aureus.

\begin{tabular}{|c|c|c|c|}
\hline & Leaves $(\mathbf{m m})$ & Stems $(\mathbf{m m})$ & Roots $(\mathbf{m m})$ \\
\hline Crude extract & $10.33 \pm 0.17^{\mathrm{A}}$ & $6.67 \pm 0.33^{\mathrm{B}}$ & $6.33 \pm 0.17^{\mathrm{A}}$ \\
\hline Methanolic extracts & $8.67 \pm 0.67^{\mathrm{B}}$ & $9.00 \pm 0.58^{\mathrm{A}}$ & $6.00 \pm 0.33^{\mathrm{A}}$ \\
\hline Acetone & $6.17 \pm 0.17^{\mathrm{C}}$ & $6.17 \pm 1.17^{\mathrm{B}}$ & $6.67 \pm 0.00^{\mathrm{A}}$ \\
\hline P value & 0.0016 & 0.005 & 0.1715 \\
\hline
\end{tabular}

Table $1 \mathrm{~b}$ : Zone diameter $(\mathrm{mm})$ of growth inhibition recorded as per the solvents used in extraction against $S$. aureus.

\begin{tabular}{|c|c|c|c|}
\hline & Crude extract $(\mathbf{m m})$ & Methanol $(\mathbf{m m})$ & Acetone $(\mathbf{m m})$ \\
\hline Leaves & $10.33 \pm 0.33^{\mathrm{A}}$ & $8.67 \pm 0.67^{\mathrm{B}}$ & $6.17 \pm 0.17^{\mathrm{A}}$ \\
\hline Stems & $6.67 \pm 0.33^{\mathrm{B}}$ & $9.00 \pm 0.58^{\mathrm{A}}$ & $6.17 \pm 0.17^{\mathrm{A}}$ \\
\hline Roots & $6.33 \pm 0.17^{\mathrm{B}}$ & $6.67 \pm 0.33^{\mathrm{C}}$ & $6.00 \pm 0.00^{\mathrm{A}}$ \\
\hline P value & 0.0001 & 0.0460 & 0.6297 \\
\hline
\end{tabular}

Table 2: Phytochemical Compounds in leaves, stems and roots of $T$. diversifolia.

\begin{tabular}{|c|c|c|c|c|}
\hline Phytochemicals & Plant parts & Methanolic & Acetone & Aqueous \\
\hline \multirow{3}{*}{ Saponins } & Leaves & + & - & + \\
\hline & Stems & - & - & + \\
\hline & Roots & - & - & + \\
\hline \multirow{3}{*}{ Flavonoids } & Leaves & + & + & + \\
\hline & Stems & + & + & + \\
\hline & Roots & + & + & + \\
\hline \multirow{3}{*}{ Alkaloids } & Leaves & + & + & + \\
\hline & Stems & + & + & + \\
\hline & Roots & + & - & + \\
\hline \multirow{3}{*}{ Steroids } & Leaves & + & + & - \\
\hline & Stems & - & - & + \\
\hline & Roots & + & - & - \\
\hline \multirow{3}{*}{ Terpenoids } & Leaves & - & - & + \\
\hline & Stems & - & + & - \\
\hline & Roots & - & - & - \\
\hline \multirow{3}{*}{ Tannins } & Leaves & + & + & + \\
\hline & Stems & + & + & + \\
\hline & Roots & + & + & + \\
\hline \multirow{3}{*}{ Glycosides } & Leaves & + & + & + \\
\hline & Stems & + & - & + \\
\hline & Roots & + & - & - \\
\hline
\end{tabular}

Key + Presence of metabolites

- Absence of metabolites
Table 2a: Zone diameter $(\mathrm{mm})$ of growth inhibition of extracts of three plant parts against $E$. coli.

\begin{tabular}{|c|c|c|c|}
\hline & Leaves $(\mathbf{m m})$ & Stems $(\mathbf{m m})$ & Roots $(\mathbf{m m})$ \\
\hline Crude extract & $7.33 \pm 0.33^{\mathrm{A}}$ & $7.33 \pm 0.33^{\mathrm{AB}}$ & $7.33 \pm 0.29^{\mathrm{A}}$ \\
\hline Methanolic extract & $7.00 \pm 0.58^{\mathrm{A}}$ & $7.67 \pm 0.33^{\mathrm{A}}$ & $6.50 \pm 0.33^{\mathrm{AB}}$ \\
\hline Acetone & $6.33 \pm 0.33^{\mathrm{A}}$ & $6.33 \pm 0.33^{\mathrm{B}}$ & $6.00 \pm 0.00^{\mathrm{B}}$ \\
\hline P value & 0.3170 & 0.0685 & 0.0270 \\
\hline
\end{tabular}

Table $2 \mathrm{~b}$ : Zone diameter $(\mathrm{mm})$ of growth inhibition recorded as per the solvents used in extraction against $E$. coli.

\begin{tabular}{|c|c|c|c|}
\hline & Crude extract $(\mathbf{m m})$ & Methanol $(\mathbf{m m})$ & Acetone $(\mathbf{m m})$ \\
\hline Leaves & $7.33 \pm 0.33^{\mathrm{A}}$ & $7.00 \pm 0.58^{\mathrm{A}}$ & $6.33 \pm 0.33^{\mathrm{A}}$ \\
\hline Stems & $7.33 \pm 0.33^{\mathrm{A}}$ & $7.67 \pm 0.33^{\mathrm{A}}$ & $6.37 \pm 0.33^{\mathrm{A}}$ \\
\hline Roots & $7.50 \pm 0.89^{\mathrm{A}}$ & $7.33 \pm 0.33^{\mathrm{A}}$ & $6.00 \pm 0.00^{\mathrm{A}}$ \\
\hline P value & 0.1842 & 0.5787 & 0.6297 \\
\hline
\end{tabular}

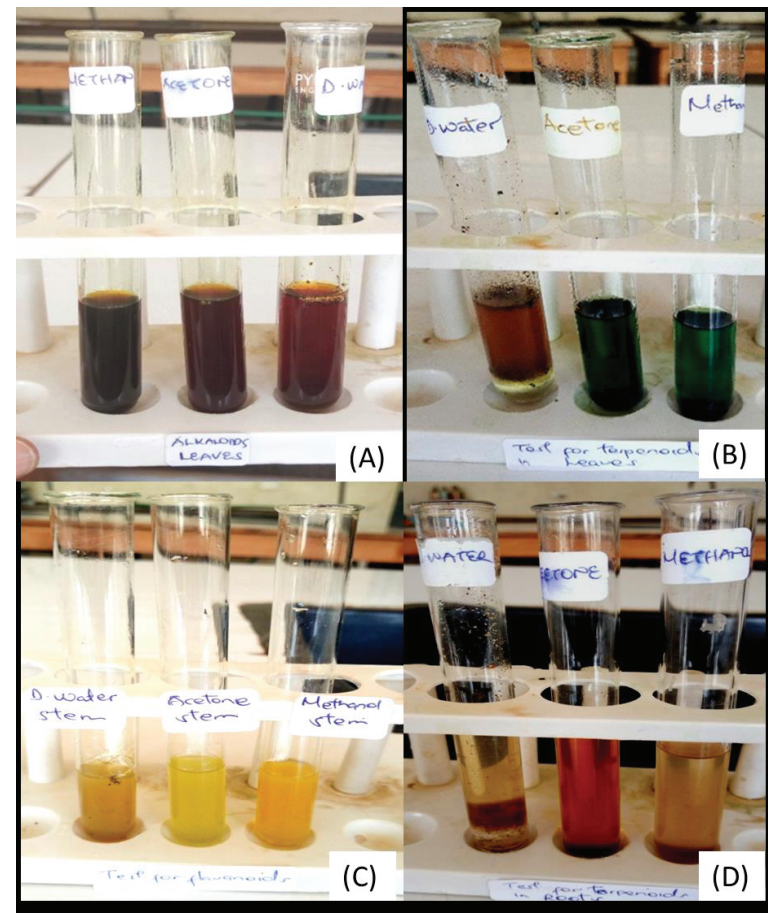

Figure 2: Showing test for alkaloids (A), terpenoids (B), flavonoids (C) and terpenoids in roots (D).

was recorded by crude extracts (10.33) followed by methanolic extract (8.67) and lastly acetone (6.17) Figure 3.

There were significant differences in zones of inhibition from crude extracts, methanolic extracts and acetone extracts(0.005) and methanolic extract recording the highest zone of inhibition (9.00) followed by crude extract (6.67) and acetone (6.17). There were no remarkable distinction in zones of inhibition from the three extracts in roots $(\mathrm{P}=0.1715)$.

There were significant differences in zones of inhibition in leaves, stems and roots from crude extracts $(\mathrm{p}=0.0001)$, leaves recording the highest zone of inhibition (10.33) followed by stems (6.67) then roots recording the least (6.33). In methanolic extract, there were significant differences in leaves, stems and roots $(\mathrm{p}=0.0460)$ stems recording the highest zone of inhibition (9.00) followed by the leaves (8.67) then the roots.

Citation: Merciline O, Dominic M (2020) Phytochemical screening and antimicrobial activity of crude extract of Tithonia diversifolia. Open J Biol Sci 5(1): 028-033 
There were no significant differences in zones of inhibition as recorded by leaves, stems and roots from acetone extracts $(\mathrm{p}=0.6297)$ (Table $1 \mathrm{~b})$.

There were no significant differences in zones of inhibition from crude extracts, methanolic extracts and acetone extract from prepared leaves $(\mathrm{p}=0.3170)$, the highest zone of inhibition was recorded by the crude extract against E. coli (7.33) followed by methanolic extract (7.00) and acetone (6.33). There were no significant differences in zones of inhibition from crude, methanolic and acetone extract from prepared stems $(p=0.0685)$ and methanolic extract recording the highest zone of inhibition (7.67) followed by crude extract (7.33) and acetone (6.33).In roots there were significant differences in zones of inhibition from crude extracts, methanolic extract recorded in roots $(\mathrm{p}=0.0270)$, crude extract recording the highest zone of inhibition (7.33) followed by methanolic extract (6.50) and acetone (6.00).

There were no significant differences in zones of inhibition from leaves, stems and roots from crude extract against $E$. coli $(\mathrm{p}=0.1842)$, with roots recording the highest zone of inhibition (7.50) followed by both stems and leaves recording (7.33) each. There were no significant differences from leaves, stems and roots as recorded in methanolic extract $(\mathrm{p}=0.5787)$, the stems recorded the highest zone of inhibition (7.67) followed by the roots (7.33) then the leaves (7.00). There were no significant differences in zones of inhibition as recorded by acetone extracts $(p=0.6297)$. The roots recorded the least zone of inhibition (6.00) followed by leaves (6.33) then stems recording the highest zone of inhibition (6.37) (Table 2b).

There were no significant differences in zones of inhibition from crude extracts, methanolic and acetone extract from prepared leaves $(\mathrm{p}=0.0685)$. The highest zone of inhibition was recorded by the methanolic extract against $P$. areuginosa $(7.67)$ followed by crude extract (6.67) and acetone (6.33). There were significant differences in zones of inhibition from prepared roots $(\mathrm{p}=0.0078)$ and methanolic extract recorded the highest zone of inhibition (8.00) followed by crude extract (6.67) and acetone (6.17). With the extracts from the stem there were also significant differences $(\mathrm{p}=0.0135)$, methanolic extract showing highest zone of inhibition (7.33) followed by crude extract (6.67) and acetone (6.00) (Table 3a).

There were no significant differences in zones of inhibition from leaves, stems, and roots from crude extract $(\mathrm{p}=0.1000)$, with all the plant parts showing the same value of zone of inhibition (6.67). In methanolic extract, there were no significant differences in leaves, stems and roots from methanolic extract $(p=0.3945)$ with the leaves recording the highest zone of inhibition followed by stems(7.67) and roots (7.33) Lastly there were no significant differences in zones of inhibition from leaves, stems and roots as recorded by acetone extract $(p=0.6297)$ (Table $3 b)$.

There were no significant differences in zones of inhibition from crude extracts, methanolic extract and acetone extracts from prepared leaves of Tithonia diversifolia, $(\mathrm{p}=0.1222)$. The

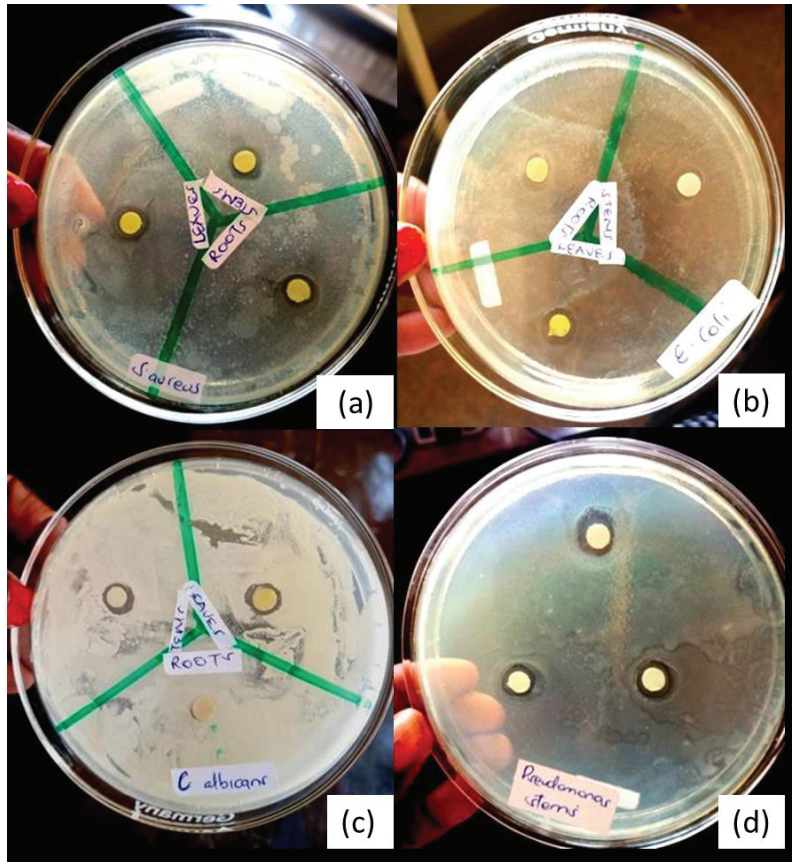

Figure 3: Zones of inbition against S.aureus (a)

P.aureginosa (d).

Table 3a: Zone diameter $(\mathrm{mm})$ of growth inhibition of extracts from the three plant parts against $P$. aeruginosa.

\begin{tabular}{|c|c|c|c|}
\hline & Leaves $(\mathbf{m m})$ & Roots $(\mathbf{m m})$ & Stems $(\mathbf{m m})$ \\
\hline Crude extract & $6.67 \pm 0.33^{\mathrm{AB}}$ & $6.67 \pm 0.17^{\mathrm{B}}$ & $6.67 \pm 0.33^{\mathrm{AB}}$ \\
\hline Methanolic extract & $7.67 \pm 0.33^{\mathrm{A}}$ & $8.00 \pm 0.33^{\mathrm{A}}$ & $7.33 \pm 0.29^{\mathrm{A}}$ \\
\hline Acetone & $6.33 \pm 0.33^{\mathrm{B}}$ & $6.17 \pm 0.00^{\mathrm{B}}$ & $6.00 \pm 0.17^{\mathrm{B}}$ \\
\hline P value & 0.0685 & 0.0078 & 0.0135 \\
\hline
\end{tabular}

Table 3b: Zone diameter ( $\mathrm{mm}$ ) of growth inhibition recorded as per the solvents used in extraction against $P$. areuginosa.

\begin{tabular}{|l|l|l|l|} 
& Crude extract $(\mathbf{m m})$ & Methanol $(\mathbf{m m})$ & Acetone $(\mathbf{m m})$ \\
\hline Leaves & $6.67 \pm 0.33^{\mathrm{A}}$ & $8.00 \pm 0.29^{\mathrm{A}}$ & $6.33 \pm 0.33^{\mathrm{A}}$ \\
\hline Stems & $6.67 \pm 0.33^{\mathrm{A}}$ & $7.67 \pm 0.33^{\mathrm{A}}$ & $6.17 \pm 0.17^{\mathrm{A}}$ \\
\hline Roots & $6.67 \pm 0.17^{\mathrm{A}}$ & $7.33 \pm 0.33^{\mathrm{A}}$ & $6.00 \pm 0.00^{\mathrm{A}}$ \\
\hline P value & 1.000 & 0.3944 & 0.5787 \\
\hline
\end{tabular}

highest zone of inhibition was recorded by the methanolic extract against $C$. albicans (8.00)) followed by crude extract (6.83) and acetone (6.50). There were no significant differences in zones of inhibition from prepared stem $(\mathrm{p}=0.2963)$. Crude extract recorded the highest zone of inhibition (7.33) followed by methanolic extract (7.17) and acetone (6.17). With the extracts from the roots there was a significant differences $(p=0.0010)$, methanolic extract showing highest zone of inhibition (9.00) followed by crude extract and acetone each obtaining a value of (6.00) (Table 4a).

In all the observations made and values recorded there were no significance differences in zones of inhibition from leaves, stems and roots with crude extracts $(p=0.652)$, methanol $(p=0.1291)$ and acetone $(0.2963)$. the highest zones of inhibition were recorded stems in crude extract(7.33), roots in methanol(9.00) and both leaves and stems in acetone(6.50). 
Table 4a: Zone diameter $(\mathrm{mm})$ of growth inhibition of extracts from the three plant parts against Candida albicans.

\begin{tabular}{|c|c|c|c|}
\hline & Leaves $(\mathbf{m m})$ & Stems $(\mathbf{m m})$ & Roots $(\mathbf{m m})$ \\
\hline Crude extract & $6.83 \pm 0.44^{\mathrm{AB}}$ & $7.33 \pm 0.00^{\mathrm{A}}$ & $6.00 \pm 0.00^{\mathrm{B}}$ \\
\hline Methanolic extract & $8.00 \pm 0.58^{\mathrm{A}}$ & $7.17 \pm 0.44^{\mathrm{A}}$ & $9.00 \pm 0.58^{\mathrm{A}}$ \\
\hline Acetone & $6.50 \pm 0.29^{\mathrm{B}}$ & $6.50 \pm 0.29^{\mathrm{A}}$ & $6.00 \pm 0.00^{\mathrm{B}}$ \\
\hline P value & 0.1222 & 0.2963 & 0.0010 \\
\hline
\end{tabular}

Table 4b: Zone diameter ( $\mathrm{mm}$ ) of growth inhibition recorded as per the solvents used in extraction against.

\begin{tabular}{|c|c|c|c|}
\hline & Crude extract $(\mathbf{m m})$ & Methanol $(\mathbf{m m})$ & Acetone $(\mathbf{m m})$ \\
\hline Leaves & $6.83 \pm 0.44^{\mathrm{AB}}$ & $8.00 \pm 0.58^{\mathrm{A}}$ & $6.50 \pm 0.29^{\mathrm{A}}$ \\
\hline Stems & $7.33 \pm 0.33^{\mathrm{A}}$ & $7.17 \pm 0.44^{\mathrm{A}}$ & $6.50 \pm 0.29^{\mathrm{A}}$ \\
\hline Roots & $6.00 \pm 0.00^{\mathrm{B}}$ & $9.00 \pm 0.58^{\mathrm{A}}$ & $6.00 \pm 0.00^{\mathrm{A}}$ \\
\hline P value & 0.0652 & 0.1291 & 0.2963 \\
\hline
\end{tabular}

\section{Discussion}

The results for chemical substances analysis of the extracts of Tithonia diversifolia indicated the presence of flavonoids, alkaloids and tannin in all the plant parts and in all the solvents used. The existence of alkaloids, glucosides and tannins in the leaves extracts of Tithonia diversifolia are in accordance to the results of while the findings of the absence of saponins in acetone extracts is contrary to his findings. Steroids are the least secondary metabolites found in the leaves stems and roots of Tithonia diversifolia according to the obtained results. As the leaves leads in the number of metabolites they contain which is accordance to my findings, they contain all the tested secondary metabolites except terpanoids in methanolic, acetone extracts and saponins in acetone extracts. According to Adesokan and Akanji [7]. Flavonoids contain anti-spasmodic antifungal and antibacterial activity and its presence in T. diversifolia gives the plant ability to be employed in the cure of stomach aches, diarrhea and microbial infections such as urinary and general diseases. The presence of saponins shows the ability of the plant to be used in the treatment inflammation related diseases due to its inflammatory properties. The roots on the other hand had negative results recorded which authenticated the absence of the metabolites, a good example being the terpenoids. The presence of glycosides indicated the plant can be used in the treatment of heart related diseases [8]. The presence or absence of these secondary metabolites may be due to an explainable reason for the difference in their ability to dissolve in either of the solvents that recorded the absence of these metabolites e.g. saponins were present in methanolic and distilled water extracts reasons being may be saponins best dissolves in the two solvents other than acetone [9-33].

Results obtained from antimicrobial activity testing of crude extracts of Tithonia diversifolia, Tables 3-10 shows variability in the inhibitory activity of Tithonia diversifolia crude extracts against the test organisms. Among all the microorganisms used Staphylococcus aureus is much more susceptible to the crude leaves extracts showing the highest inhibitory zone followed by methanolic extracts then acetone shown by letters $\mathrm{A}, \mathrm{B}$ and $\mathrm{C}$ respectively and therefore a significant differences in the solvents used, preferably crude leaves extract should be used may be because some of the metabolites might have been well dissolved in distilled water. Methanolic extracts of stems showed the largest zone of inhibition against S. aureus (Table 3) reasons being maybe there were some metabolites that inhibited the growth of $S$. aureus unlike the other plant parts.

There is no significant difference in the antimicrobial activity of the stems and leaves extracts against E. coli leaving the crude roots extracts having the highest inhibitory zone therefore creating a significant differences. In line with this acetone root extracts did not show any inhibitory characteristics. $S$. aureus gram positive bacteria are more susceptible to antimicrobial agents compared to $E$. coli and $P$. aeruginosa gram negative bacteria this can be attributed to the nature of their cell wall. The gram negative bacteriais characterisd by a thick cell wall because their outer phospholipid membrane carries lipopolysaccharide components making their cell wall impermeable to antimicrobial substances. Gram positive bacteria have only a peptidoglycan layer which is permeable to substances.

\section{Conclusion}

Chemical substance analysis of the crude extract of $T$. diversifolia discloses presence of saponins, glycosides flavonoids, , steroids, terpenoids, tannins and alkaloids from methanolic, acetone and aqueous extracts. The present investigation showed revealed a general trend that the leaves had the highest antimicrobial activity against test microorganisms followed by stems and roots respectively against the entire test organisms used. The presence of these phytochemical and their ability to react against tests organisms indicates that the leaves, roots and stems of T. diversifolia could serve as basic ingredients in drug making for use in treatment of various ailments.

\section{References}

1. Orwa C, Mutua A, Kindt R, Jamnadass R, Simons A (2009) Agroforestry Database: A Tree Reference and Selection Guide. Link: https://bit.ly/2UHMHYb

2. Bork PM, Schmitz MC, Weimann C, Kist M, Heinrish M (1996) Nahua Indian medicinal plants (Mexico): Inhibitory activity on NF-Kb as an antiinflammatory model and anti-bacterial effects. Phytomedicine 3: 263-269. Link: https://bit.ly/3e0e73h

3. Adedapo AA, Shabi OO, Adedokun OA (2005) Antihelminthic efficacy of the aqueous extract of Euphorbia hirta (Linn.) in Nigerian dogs. Vet Arch 75: 3947. Link: https://bit.ly/3fdjKv8

4. Sofowora A (1999) African Medicinal Plants. Medicinal Plant Research in Nigeria 13: 455-462.

5. Evans CW (1999) Trease and Evans Pharmacognosy. 15 $5^{\text {th }}$ Edition. Bailliere Tindall Press 245-263.

6. Harbone JB (1993) Phytochemical Methods; a Guide to Modern Techniques of Plant Analysis. $5^{\text {th }}$ Ed. Prentice and Hall 68-80.

7. Adesokan AA, Akanji MA (2010) Antimalarial bioactivity Enantiachlorantha stem bark. Medicinal plants: phytochemistry, pharmacology and therapeautics 4: 441-447. Link: https://bit.ly/3ebFwPX

8. Fatoba PO, Omojasola PF, Awe S, Ahmed FG (2003) Phytochemical screening of some selected tropical African Mosses. Nigerian Society for Experimental Biology (NISEB) Journal 3: $49-52$ 
9. Adiquzel A, Ozer H, Sokmen M, Gulluce M, Sokmen A, et al. (2009) Antimicrobial activity of essential oil and methanol extract of Nepetacataria. Pol J Microbial 58: 69-76. Link: https://bit.ly/2MWmalO

10. B Valentine Bhimba (2010) antimicrobial activity of characterization of secondary metabolites isolated from mangrove plant Avicenniaofficinalis Claudia Di Giacomo, Luca Vanella and Rosaria Acquaviva. Effects of Tithonia diversofolia (Helms). A Gray, Extract on Adipocyte Differential

11. Cowan MM (1999) Plant products as antimicrobial agents. Clinical Microbial Rev 564-582. Link: https://bit.ly/37rqBOJ

12. Estelle Levitin Karen (2003) $3^{\text {rd }}$ edition, McGraw Hill limited 314-333.

13. Gortzi O, Lalas S, Chinoul Taknis J (2008) Re-evaluation of bioactivity and antimicrobial activity of Myrtuscommunis extracts before and after encapsulation in liposomes. Eur Food ResTechnology 226: 583-590. Link: https://bit.ly/30FzmDp

14. Hostettmann K (1999) Strategy for the biological and chemical evaluation of plant extracts. Pure App Chem 1-9. Link: https://bit.ly/3fk6vJ1

15. Irvine FR (1961) Woody plants of Ghana, London, Oxford University press Link: https://bit.ly/2UGRBVs

16. John OK (2009) Medicinal Plants of East Africa, $3^{\text {rd }}$ edition .University of Nairobi press. 270: 289-290.

17. Journal of East Africa Natural history (2013) A journal of Biodiversity 102: 174175. Link: https://bit.ly/30EOROo

18. Maciel MAM, Pinto AC, Veiga JR, Grynberg NF, Echevania A (2002) Medicinal plants, the need for multi displinary scientific studies. Quim Nova 25: 429438. Link: https://bit.ly/3hnEUsg

19. Nora M, Upadhyay SN, Hazra J, kawin L (2007) Pharmacological profile of Tithonia diversofolia A. GRAY a comprehensive review. i 183-185.

20. Mayee R, Thosar A (2011) Evaluation of Lantana camara for antiurolithiatic and antioxidant activities in rats. Int $\mathrm{J}$ Pharm Clinical Res 3: 10-14. Link: https://bit.ly/3cXYgAM

21. Ogundare AO (2007) Antimicrobial effect of Tithonia diversifolia and Jatrophagossypifoliaextracts. Trends in Applied Sciences Research 2: 145150. Link: https://bit.ly/3e5y4Ww

22. Owoyele VB, Wuraola CO, Soladoye AO, Olaleye SB (2004) Studies on the antiinflammatory and analgesic properties of Tithonia diversifolialeaf extract J Ethnopharmacol 90: 317-321. Link: https://bit.ly/3e0rAb8

23. Oyeleke SB, Dauda BEN, Boye OA (2008) Antibacterial activity of Ficuscapensis African Journal of Biotechnology 7: 1414-1417. Link: https://bit.ly/2MWkLvy

24. Prasannabalaji N, Muralitharan G, Sivanandan RN, Kumaran S, Pugazhvendan SR (2012) Antibacterial activities of some Indian traditional plant extracts. Asian Pacific Journal of Tropical Disease 2: 291-295. Link: https://bit.ly/3e1FwSj

25. Ross IA (1999) Medicinal plants of the world. Chemical constituents traditional and modern medical uses. New Jersey Humana Press. Link: https://bit.ly/2YA9UwN

26. Rwangabo PC, Claeys M, Pieters L, Corthout J, Vanden Berghe DA, et al. (1988) Umuhengerin. Anew antimicrobially active flavonoids from Lantana trifolia. Journal Prod 51: 966-968. Link: https://bit.ly/3hmo64R

27. Sparg SG, Light ME, Stadan JV (2004) Biological Activities and Distribution of Plant Saponins. J Ethnopharmacol 94: 219-243 . Link: https://bit.ly/3d1PMIS

28. Sugumaran S, Raj ADS (2010) Medicinal plants of sacred groves in Kanyakumari district south Western Ghats. Indian J Traditional Knowledge 9 ; 291-299. Link: https://bit.ly/30Etk60

29. Schulz V, Hansel R, Tyler VE (2001) Rational Phyto therapy. A physician's guide to herbal medicine, $4^{\text {th }}$ edition, Berlin, Springer-Verlag. Link: https://bit.ly/3fonuds

30. Taiwo SS, Oyekanmi BA, Adesiji YO, Opaleye OO, Adeyeba OA (2007) In vitro antimicrobial activity of crude extracts of Citrus aurantifolia Linn and Tithonia diversifolia Poaceae on clinical bacteria isolates. International Journal of Tropical Medicine 2: 113-117. Link: https://bit.ly/3fdkO26

31. Swamy TA, Obey KJ, Edwin M, Timothy LT (2016) Bioassay screening of the Ethanolic extract of Tithonia diversifolia leaves on selected microorganisms. International Journal of Bioassays 4794-4798. Link: https://bit.ly/3hinyNo

32. Gurib-Fakim A, Sewraj MD, Gueho J, Dulloo E (1996) Medicinal Plants of Rodrigues. International Journal of Pharmacology 34: 12-14. Link: https://bit.ly/3d0kT7R

33. Madureira MC, Martins AP, Gomes M, Paiva J, Cunha AP, et al. (2002) Antimalarial activity of medicinal plants used in traditional medicine in S. Tome and Principe Island. J Ethnopharmacol 81: 23-29. Link: https://bit.ly/2XYxmVm

\section{Peertechz Publications}

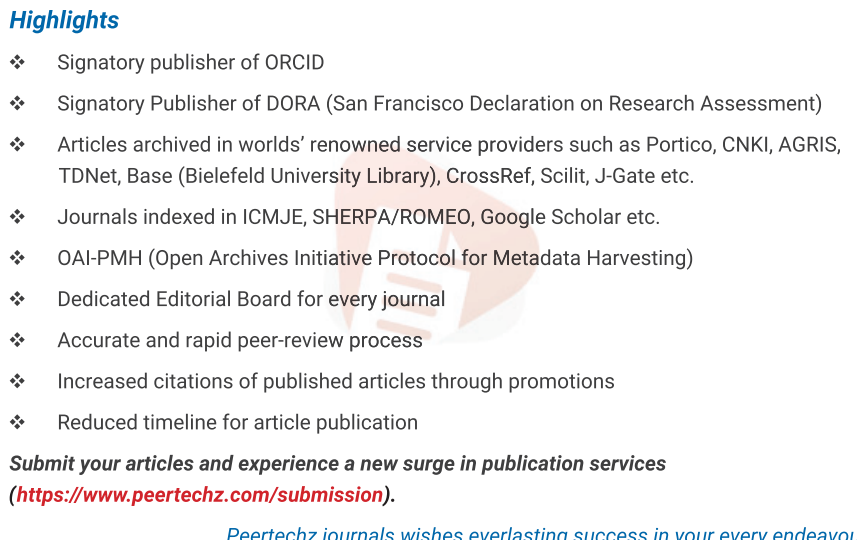

Copyright: (c) 2020 Merciline 0, et al. This is an open-access article distributed under the terms of the Creative Commons Attribution License, which permits unrestricted use, distribution, and r eproduction in any medium, provided the original author and source are credited.

Citation: Merciline O, Dominic M (2020) Phytochemical screening and antimicrobial activity of crude extract of Tithonia diversifolia. Open J Biol Sci 5(1): 028-033. DOI: https://dx.doi.org/10.17352/ojbs.000021 